\title{
HUBUNGAN SIKAP DENGAN KEPATUHAN PERAWAT DALAM MENCUCI TANGAN DI RUANG RAWAT INAP RUMAH SAKIT SWASTA
}

\author{
Eunike Kristien Doloksaribu ${ }^{1}$, Nathalia Lintin ${ }^{2}$, Revina Marthalita Sukma Dewi ${ }^{3}$, Martina \\ Pakpahan $^{4 *}$, Dora Irene Purimahua ${ }^{5}$
}

\author{
${ }^{1,2,3}$ Head Office Siloam Hospital Group, Jalan Jendral Sudirman, Tangerang, Banten \\ Email: eunike.kristienfon16@gmail.com \\ ${ }^{4,5}$ Fakultas Keperawatan Universitas Pelita Harapan, Jalan Jendral Sudirman, Tangerang, Banten \\ *Email: martina.pakpahan@uph.edu \\ *Corresponding Author
}

Masuk: 12-05-2021, revisi: 25-09-2021, diterima untuk diterbitkan: 05-10-2021

\begin{abstract}
ABSTRAK
Infeksi terkait pelayanan kesehatan atau infeksi nosokomial masih menjadi masalah utama yang terjadi di rumah sakit. Hal ini menyebabkan perawatan yang berkepanjangan, peningkatan resistensi terhadap antimikroba, peningkatan morbiditas dan mortalitas, biaya perawatan tinggi dan menurunnya mutu pelayanan. Perawat paling banyak berinteraksi dengan pasien maka kepatuhan perawat dalam mencuci tangan dapat memengaruhi penyebaran infeksi nosokomial. Penelitian bertujuan untuk mengetahui hubungan sikap dengan kepatuhan perawat mencuci tangan di Ruang Rawat Inap di Satu Rumah Sakit Swasta di Jakarta. Penelitian merupakan kuantitatif korelasional dengan desain cross-sectional. Jumlah sampel yaitu 49 responden yang diperoleh menggunakan purposive sampling. Instrumen berupa kuesioner dan lembar observasi. Uji validitas dan reliabilitas kuesioner didapatkan Cronbach Alpha 0,909. Observasi diantara peneliti didapatkan hasil uji kappa 0,615. Analisis menggunakan analisis univariat dan bivariat. Persetujuan etik didapatkan dari Komite Etik Fakultas Keperawatan Universitas Pelita Harapan. Pada analisis univariat diketahui sebesar $27(55,1 \%)$ perawat memiliki sikap baik dalam mencuci tangan dan sebesar 39 (79,6\%) perawat tidak patuh mencuci tangan. Pada analisis bivariat dengan uji Chi-Square menunjukkan bahwa tidak terdapat hubungan sikap perawat dengan kepatuhan perawat mencuci tangan di ruang rawat inap di satu Rumah Sakit Swasta di Jakarta ( $p$ value 0,716, CI $95 \%$ ). Penelitian berikutnya dapat meneliti faktor-faktor lain yang memengaruhi kepatuhan perawat mencuci tangan seperti pengetahuan, motivasi, ketersediaan fasilitas cuci tangan, beban kerja, supervisi dan role model.
\end{abstract}

Kata Kunci : Cuci tangan; Kepatuhan; Perawat; Rawat Inap; Sikap

\begin{abstract}
Health Care-Associated Infection (HAI) or Nosocomial infection is still a major problem that occurs in hospitals. This results in prolonged treatment, increased resistance to antimicrobials, increased morbidity and mortality, high maintenance costs and decreased quality of care. Nurses interact the most with patients, so nurse compliance in washing hands can affect the spread of nosocomial infections. This study aims to determine the correlation between nurses' attitudes and compliance with hand washing in an inpatient room at a private hospital in Jakarta. The study is quantitative correlational used cross-sectional design. The total samples was 49 respondents obtained using purposive sampling technique. This study used a questionnaire instrument and observation sheet. Validity and reliability tests for the questionnaire obtained Cronbach Alpha 0.909. Observations among researchers obtained the kappa test results of 0.615.The analysis used univariate and bivariate analyzes. The ethical approval was obtained from the Ethics Committee of the Faculty of Nursing, Universitas Pelita Harapan. In the univariate analysis, it was showed that 27 (55.1\%) of nurses had a good attitude in hands washing and 39 (79.6\%) of nurses did not comply with hands washing. In the bivariate analysis using the Chi-Square test, it showed that there was no correlation between attitudes and nurse compliance in hand washing in an inpatient room at a private hospital in Jakarta ( $p$ value 0.716, 95\% CI). Future studies can examine other factors that influence nurse compliance in hand washing compliance such as knowledge, motivation, availability of hand washing facilities, workload, monitoring and role models.
\end{abstract}

Keywords: Hand washing; Compliance; Nurse; Inpatient; Attitude 


\section{PENDAHULUAN}

\section{Latar Belakang}

Health Care-Associated Infection (HAI) atau Infeksi yang berkaitan terhadap pelayanan kesehatan dikenal juga sebagai infeksi "nosokomial", sebagai infeksi yang terjadi pada pasien selama dirawat di rumah sakit atau sarana perawatan kesehatan lain dan juga dapat timbul setelah pasien pulang (World Health Organization (WHO), 2017). Data WHO (2017) menyatakan setiap tahun di seluruh dunia diperkirakan ratusan juta pasien mengalami infeksi nosokomial. Pada negara dengan penghasilan rendah dan menengah beban yang dirasakan beberapa kali lipat lebih tinggi dibandingkan pada negara berpenghasilan tinggi. Infeksi nosokomial menjadikan perawatan di rumah sakit berkepanjangan, kecacatan jangka panjang, peningkatan resistensi mikroorganisme terhadap antimikroba, biaya tambahan yang sangat besar untuk sistem kesehatan, biaya tinggi bagi pasien dan keluarganya, dan kematian yang tidak perlu (WHO, 2017). Perhimpunan Rumah Sakit Seluruh Indonesia (PERSI), (2020) menyatakan bahwa hal ini dapat memengaruhi mutu pelayanan di fasilitas kesehatan.

Peraturan Kementerian Kesehatan nomor 27 tahun 2017 tentang Pedoman Pencegahan dan Pengendalian Infeksi di Fasilitas Pelayanan Kesehatan menjelaskan bahwa Pencegahan dan Pengendalian Infeksi (PPI) merupakan upaya menghindari dan mengurangi kejadian infeksi pada pasien, petugas, pengunjung, dan masyarakat di sarana kesehatan. Program PPI untuk infeksi nosokomial sebagai komponen patient safety. Lebih lanjut kementerian kesehatan menegaskan bahwa hasil penelitian menunjukkan infeksi nosokomial terjadi karena petugas tidak patuh mencuci tangan, dimana di Indonesia rata-rata kepatuhan mencuci tangan hanya 20\%-40\% (Kemenkes, 2009). Cuci tangan menjadi strategi pengendalian infeksi nosokomial. Perawat sebagai petugas kesehatan yang paling sering berhubungan langsung dengan pasien, sehingga peran perawat besar dalam memengaruhi kejadian infeksi nosokomial.

Studi pendahuluan yang dilakukan peneliti berupa observasi terhadap 49 perawat pada bulan Januari-Februari 2019 di ruang rawat inap di satu Rumah Sakit Swasta, ditemukan jika perawat tidak mencuci tangan saat kontak dengan pasien ataupun setelah kontak dengan area disekitar pasien, perawat tidak menerapkan prosedur langkah mencuci tangan yang tepat sesuai standar WHO, padahal telah tersedia fasilitas handrub yang diletakkan di setiap depan pintu kamar pasien. Selain itu, hasil wawancara terhadap 20 orang perawat di bulan Februari, didapatkan bahwa sebanyak $15 \%$ perawat mengatakan jarang mencuci tangan dikarenakan tidak sempat melakukannya, akibat banyak pekerjaan yang membuat mereka ingin cepat melakukan tugas yang lainnya, dan sebanyak $85 \%$ mengatakan tidak perlu lagi untuk mencuci tangan karena sudah menggunakan sarung tangan. Pada tahun 2019, sasaran mutu kepatuhan cuci tangan yang ditargetkan satu rumah sakit swasta ini yaitu sebesar $85 \%$, padahal capaian yang diperoleh diruang rawat inap sebesar 79\%. Hal ini masih dibawah standar yang ditargetkan. Padahal kualitas asuhan keperawatan berhubungan langsung dengan kejadian dan prevalensi Infeksi nosokomial (Boev and Kiss, 2017).

Murni et al., (2015) menyebutkan bahwa intervensi pengendalian infeksi multifaset efektif dalam mengurangi angka infeksi nosokomial, meningkatkan penggunaan antibiotik secara rasional, meningkatkan kepatuhan kebersihan tangan, dan dapat mengurangi kematian anak yang sedang mendapatkan perawatan khususnya di negara berkembang. Penelitian Mehta et al., (2014) menemukan bahwa mencuci tangan menjadi satu-satunya praktik kebersihan yang paling efektif untuk meminimalkan infeksi nosokomial ketika petugas kesehatan mencuci tangan saat sebelum dan setelah kontak dengan pasien. Studi lainnya yang dilakukan oleh Haverstick et al., (2017) menemukan adanya hubungan yang signifikan antara kebersihan tangan dengan tingkat infeksi 
akibat Enterococci yang resisten vankomisin dan Staphylococcus Aureus yang resisten methicillin setelah penerapan intervensi kebersihan tangan. Dari latar belakang dan fenomena yang diuraikan, tujuan penelitian untuk mengetahui hubungan sikap dengan kepatuhan perawat dalam mencuci tangan di Ruang Rawat Inap di Satu Rumah Sakit Swasta.

\section{METODE PENELITIAN}

\section{Desain penelitian}

Penelitian ini merupakan penelitian kuantitatif korelasional dengan menggunakan desain cross sectional. Penelitian dilakukan di Ruang Rawat Inap Salah Satu Rumah Sakit Swasta di Jakarta pada Mei-Juli 2019.

\section{Populasi, sampel dan pengambilan Sampel}

Populasi adalah 58 perawat yang ada di ruang rawat inap. Jumlah responden sebanyak 49 orang yang didapatkan menggunakan purposive sampling. 5 perawat merupakan responden untuk uji kappa dan 4 perawat sedang cuti melahirkan pada saat penelitian dilaksanakan.

\section{Instrumen penelitian}

Dua variabel yang diteliti yaitu sikap perawat dan kepatuhan perawat melakukan cuci tangan. Instrumen kuesioner digunakan untuk mengukur variabel sikap dan lembar observasi digunakan untuk mengukur variabel kepatuhan perawat dalam mencuci tangan. Kuesioner sikap diadopsi dari kuesioner yang dikembangkan oleh Yoku (2014). Uji validitas dan reliabilitas kuesioner dilakukan kepada 30 responden perawat di Out Patient Departement pada bulan Juni 2019. Didapatkan 15 pertanyaan valid ( $\mathrm{r}$ hitung > 0,361) dan nilai Cronbach Alpha 0,909. Lembar observasi yang digunakan dikembangkan dari Standar Operasional Prosedur Rumah Sakit untuk mencuci tangan. Peneliti mengikuti satu perawat untuk melakukan observasi sebanyak tiga kali pada shift yang berbeda. Lembar observasi digunakan saat observasi, berisikan hal-hal yang akan diamati yaitu lima momen mencuci tangan yang dilakukan perawat. Sebelum melakukan observasi, peneliti terlebih dahulu menyamakan persepsi antara peneliti satu, dua, dan tiga dengan menggunakan uji konsistensi Cohen's Kappa. Nilai uji koefisien kappa adalah 0,615 yang bermakna bahwa tidak ada perbedaan persepsi diantara peneliti.

\section{Kaji etik}

Penelitian ini mendapatkan persetujuan etik dari Komite Etik Fakultas Keperawatan Universitas Pelita Harapan dengan nomor 008/RCTC-EC/SHTBBGR/VI/2019. Peneliti memberikan informasi untuk calon responden dan Informed consent sebagai bukti kesediaan dan persetujuan responden untuk berpartisipasi dalam penelitian. Pertimbangan etik lainnya dijamin oleh peneliti dalam pelaksanaan penelitian ini, yaitu berupa; Anomity, confidentiality, Justice dan nonmaleficence.

\section{Analisa data}

Data yang berhasil dikumpulkan lalu diolah peneliti dengan tahapan editing, coding, processing, data entry dan analisis data. Data dianalisis menggunakan software statistik komputer. Analisis berupa analisis univariat dan bivariat. Analisis bivariat memakai Chi-Square Test. 


\section{HASIL DAN PEMBAHASAN}

\section{Hasil}

Hasil penelitian berupa analisis univariat dan analisis bivariat, disajikan dalam tabel 1-4.

Tabel 1. Karakteristik Perawat di Ruangan Rawat Inap di Satu Rumah Sakit Swasta di Jakarta

\begin{tabular}{llcc}
\multicolumn{3}{c}{$(\mathrm{N}=49)$} \\
\hline Karakteristik & Kategori & Frekuensi (n) & Persentase (\%) \\
& $\leq 25$ tahun & 36 & 73,4 \\
& $>25$ tahun & 13 & 26,6 \\
\hline Jenis Kelamin & Laki-Laki & 2 & 4 \\
& Perempuan & 47 & 96 \\
& & & 61,2 \\
Lama Kerja & $<1$ Tahun & 30 & 38,8 \\
& $1-5$ Tahun & 19 &
\end{tabular}

Pada tabel 1 diketahui bahwa mayoritas karakteristik responden yaitu; memiliki usia $\leq 25$ tahun yaitu sebanyak $36(73,4 \%)$ responden, berjenis kelamin wanita sebanyak 47 (96\%) responden, lama kerja $<1$ tahun yaitu sebanyak $30(61,2 \%)$ responden.

Tabel 2. Sikap Perawat dalam Mencuci Tangan di Ruang Rawat Inap di Satu Rumah Sakit Swasta di Jakarta (N=49)

\begin{tabular}{lcc}
\hline Sikap & Frekuensi (n) & Persentase (\%) \\
\hline Kurang & 27 & 55,1 \\
Baik & 22 & 44,9 \\
Total & 49 & 100,0 \\
\hline
\end{tabular}

Berdasarkan tabel 2, diketahui bahwa sebanyak 27 (55.1\%) responden memiliki sikap kurang dan sebesar $22(44.9 \%)$ responden memiliki sikap baik.

Tabel 3. Kepatuhan Perawat dalam Mencuci Tangan di Ruang Rawat Inap di Satu Rumah Sakit Swasta di Jakarta $(\mathrm{N}=49)$

\begin{tabular}{lcc}
\hline Kepatuhan & Frekuensi (n) & Persentase (\%) \\
\hline Tidak Patuh & 39 & 79,6 \\
Patuh & 10 & 20,4 \\
Total & 49 & 100,0 \\
\hline
\end{tabular}

Pada tabel 3 diketahui sebanyak 39 (79.6\%) responden tidak patuh dalam melakukan cuci tangan dan sebesar $10(20.4 \%)$ responden patuh melakukan cuci tangan.

Tabel 4. Hubungan Sikap dengan Kepatuhan Perawat dalam Melakukan Cuci Tangan di Ruang Rawat Inap di Satu Rumah Sakit Swasta di Jakarta $(\mathrm{N}=49)$

\begin{tabular}{llllllll}
\hline \multirow{2}{*}{ Sikap } & \multicolumn{4}{c}{ Kepatuhan } & \multicolumn{2}{c}{ Total } & p-value \\
& $\mathrm{n}$ & $\%$ & $\mathrm{n}$ & $\%$ & $\mathrm{~N}$ & $\%$ & \\
\hline Kurang & 22 & 44,9 & 5 & 10,2 & 27 & 55,1 & 0,716 \\
Baik & 17 & 34,7 & 5 & 10,2 & 22 & 44,9 & \\
Total & 39 & 79,6 & 10 & 20,4 & 49 & 100 & \\
\hline
\end{tabular}


Berdasarkan tabel 4, analisis bivariat uji chi-square menunjukkan bahwa sebanyak $22(44,9 \%)$ perawat memiliki sikap kurang dan tidak patuh mencuci tangan, sebanyak $17(34,7 \%)$ perawat memiliki sikap baik namun tidak patuh mencuci tangan, sebanyak $5(10,2 \%)$ perawat memiliki sikap kurang namun patuh mencuci tangan dan sebanyak $5(10,2 \%)$ perawat memiliki sikap baik dan patuh mencuci tangan. Tabel 4 juga menunjukkan bahwa $\mathrm{p}$ value sebesar 0,716 , sehingga disimpulkan tidak ditemukan hubungan sikap perawat dengan kepatuhan dalam mencuci tangan ( $p$-value $>0,05$, CI 95\%).

\section{Pembahasan}

Mencuci tangan menjadi salah satu strategi paling efektif dalam menurunkan infeksi nosokomial. Adapun 5 momen penting mencuci tangan di pelayanan kesehatan, yaitu:1) Sebelum kontak dengan pasien, 2) Sebelum tindakan asepsis, 3) Setelah terkena cairan tubuh pasien, 4) Setelah kontak dengan pasien, dan, 5) Setelah kontak dengan lingkungan pasien (WHO, 2018). Hasil penelitian menunjukkan bahwa sebanyak 39 (79.6\%) responden tidak patuh melakukan cuci tangan dan sebesar 10 (20.4\%) responden patuh melakukan cuci tangan. Hasil observasi, peneliti menemukan bahwa kepatuhan cuci tangan dipengaruhi oleh beban kerja, waktu, dan kesadaran diri. Beban kerja yang tinggi membuat perawat seringkali lupa dalam melakukan cuci tangan dikarenakan banyak hal yang harus dikerjakan sekaligus, perawat juga kurang kesadaran diri dalam mencuci tangan, dimana cuci tangan dilakukan ketika tangan sudah terlihat kotor, dan perawat tidak lagi mencuci tangan setelah memakai sarung tangan. Penelitian yang dilakukan Diwan et al., (2016) menemukan bahwa hambatan untuk menjaga kebersihan tangan terutama terkait dengan beban kerja yang tinggi, kelangkaan sumber daya, kurangnya informasi ilmiah dan persepsi bahwa kebersihan tangan tidak diprioritaskan, baik pada tingkat individu atau lembaga.

Hasil penelitian menunjukkan bahwa karakteristik mayoritas responden yaitu; memiliki usia $\leq 25$ tahun sebanyak $36(73,4 \%)$ responden, jenis kelamin wanita sebanyak 47 (96\%) responden, dan lama kerja <1 tahun yaitu sebanyak $30(61,2 \%)$ responden. Penelitian yang dilakukan Dreidi et al., (2016) menemukan bahwa ada perbedaan yang signifikan praktik mencuci tangan antara pria dan wanita, responden yang lebih tua memiliki sikap yang lebih baik dalam mencuci tangan, dan rumah sakit swasta memiliki skor kepatuhan yang jauh lebih tinggi bila dibandingkan rumah sakit pemerintah. Penelitian Setiawan (2017) menemukan adanya hubungan antara pengetahuan, masa kerja, pendidikan, dan sikap dengan perilaku perawat mencuci tangan sebelum dan sesudah implementasi keperawatan. Penelitian lainnya yang dilakukan oleh Purnawati, Junaiddin and Mewanglo (2018) menemukan adanya hubungan pengetahuan dan pendidikan perawat terhadap kepatuhan perawat dalam melakukan lima momen mencuci tangan.

Hasil penelitian menunjukkan bahwa sebanyak $17(34,7 \%)$ responden memiliki sikap baik namun tidak patuh mencuci tangan, dan sebanyak $5(10,2 \%)$ responden memiliki sikap baik dan patuh mencuci tangan. Hal ini menunjukkan bahwa sikap positif yang dimiliki perawat terhadap mencuci tangan tidak serta merta menentukan kepatuhannya dalam melakukan cuci tangan. Hasil penelitian ini sejalan dengan penelitian Ratnawati dan Sianturi (2018) di Rumah Sakit "X" Cibubur, dimana ditemukan bahwa tidak ada hubungan antar sikap responden terhadap kepatuhan menerapkan hand hygiene. Sikap perawat dalam mencuci tangan memerlukan rangsangan berupa motivasi dari lingkungan kerja, pelatihan, pendidikan, ketersediaan fasilitas cuci tangan dan adanya pengawasan dari kepala ruangan. Perilaku patuh dalam mencuci tangan tidak harus selalu di pengaruhi oleh sikap, terdapat faktor lain yang turut memengaruhi, seperti; motivasi, pengetahuan, pengalaman, beban kerja, lingkungan dan aturan dalam pekerjaan. 
Hasil penelitian juga menemukan tidak adanya hubungan antara sikap perawat dengan kepatuhan perawat dalam mencuci tangan. Hal ini sama dengan hasil penelitian Komala Dewi (2017) menemukan bahwa pengetahuan serta sikap tidak berhubungan dengan kepatuhan perawat dalam melakukan cuci tangan namun ditemukan adanya hubungan antara motivasi, fasilitas dan supervisi terhadap kepatuhan perawat mencuci tangan. Penelitian lainnya yang dilakukan Nurmala Sari and Kurnia Widi Hastuti (2019) menemukan bahwa terdapat hubungan antara pengetahuan dengan kepatuhan perawat dalam mencuci tangan, namun tidak ditemukan hubungan antara sikap dan motivasi terhadap kepatuhan perawat dalam mencuci tangan. Hasil penelitian ini berbeda dengan penelitian Amalia and Widagdo, (2016) menemukan bahwa tingkat kepatuhan petugas kesehatan untuk mempraktikkan kebersihan tangan berhubungan dengan pengetahuan dan sikap sedangkan faktor-faktor lain yang tidak berkorelasi dengan tingkat kepatuhan petugas kesehatan untuk mempraktikkan kebersihan tangan adalah usia responden, tingkat pendidikan, masa kerja, fasilitas, sosialisasi kebersihan, regulasi, dan pengawasan.

Kepatuhan terhadap standar yang ditetapkan selain bergantung pada ketersediaan fasilitas di area kerja terdekat juga dipengaruhi oleh ada atau tidaknya role model di lingkungan kerja (Hammerschmidt and Manser, 2019). Selain itu penting bagi Rumah sakit dalam membangun kepercayaan, sikap, kapasitas, dan infrastruktur yang mendukung untuk mempertahankan perilaku rutin mencuci tangan, sebab hal ini merupakan komponen penting dari strategi implementasi dalam meningkatkan kepatuhan petugas kesehatan untuk kebersihan tangan (Alfahan et al., 2016). Keyakinan perilaku positif dan keyakinan kontrol yang kuat juga diperlukan untuk meningkatkan kepatuhan kebersihan tangan (Jeong and Kim, 2016).

\section{KESIMPULAN DAN SARAN}

Hasil penelitian menunjukkan tidak terdapat hubungan sikap perawat dengan kepatuhan perawat mencuci tangan di ruang rawat inap di satu rumah sakit swasta. Kepatuhan perawat dalam mencuci tangan tidak hanya ditentukan oleh sikap perawat terhadap pentingnya mencuci tangan, tetapi juga dipengaruhi oleh faktor-faktor lainnya seperti; tingkat pengetahuan, motivasi, beban kerja, fasilitas, regulasi, supervisi, dan evaluasi.

Perlu adanya briefing di setiap pergantian shift sebagai sarana sosialisasi dan evaluasi untuk meningkatkan kepatuhan perawat dalam mencuci tangan. Selain itu, Rumah sakit melalui komite PPI perlu meningkatkan supervisi dan peran sebagai role model dalam pelaksanaan cuci tangan. Hal lain yang dapat dilakukan dengan menambahkan pelatihan atau seminar terkait mencuci tangan, memberikan apresiasi terhadap perawat yang patuh melakukan cuci tangan dan memberikan teguran ataupun sanksi terhadap perawat yang tidak patuh mencuci tangan. Penelitian berikutnya dapat meneliti faktor-faktor lain seperti pengetahuan, motivasi, ketersediaan fasilitas cuci tangan, beban kerja, pengawasan dan ketersediaan role model yang memengaruhi kepatuhan perawat dalam mencuci tangan.

\section{Ucapan Terima Kasih}

Terimakasih kepada Komite Etik Fakultas Keperawatan Universitas Pelita Harapan yang mendukung pelaksanaan penelitian ini dan kepada Lembaga Penelitian dan Pengabdian Masyarakat (LPPM) Universitas Pelita Harapan yang mendukung publikasi hasil penelitian.

\section{REFERENSI}

Alfahan, A. et al. (2016) 'In the era of corona virus: health care professionals' knowledge, attitudes, and practice of hand hygiene in Saudi primary care centers: a cross-sectional study', Journal of Community Hospital Internal Medicine Perspectives, 6(4), p. 32151. doi: 
10.3402/jchimp.v6.32151.

Amalia, R. and Widagdo, L. (2016) 'Faktor-Faktor Yang Berhubungan Dengan Tingkat Kepatuhan Tenaga Kesehatan Melakukan Cuci Tangan (Studi Kasus Di Instalasi Rawat Inap Rajawali Rsup Dr. Kariadi Semarang)', Jurnal Kesehatan Masyarakat (Undip), 4(3), pp. 2356-3346. Available at: http://ejournal-s1.undip.ac.id/index.php/jkm (Accessed: 12 April 2021).

Boev, C. and Kiss, E. (2017) 'Hospital-Acquired Infections: Current Trends and Prevention', Critical Care Nursing Clinics of North America. W.B. Saunders, pp. 51-65. doi: 10.1016/j.cnc.2016.09.012.

Diwan, V. et al. (2016) 'Understanding Healthcare Workers Self-Reported Practices, Knowledge and Attitude about Hand Hygiene in a Medical Setting in Rural India', PLOS ONE. Edited by S. Kumar, 11(10), p. e0163347. doi: 10.1371/journal.pone.0163347.

Dreidi, M. M. et al. (2016) 'Hand Hygiene Knowledge, Practices and Attitudes among Nurses and Physicians', Health, 08(05), pp. 456-462. doi: 10.4236/health.2016.85048.

Hammerschmidt, J. and Manser, T. (2019) 'Nurses' knowledge, behaviour and compliance concerning hand hygiene in nursing homes: A cross-sectional mixed-methods study', $B M C$ Health Services Research, 19(1), p. 547. doi: 10.1186/s12913-019-4347-z.

Haverstick, S. et al. (2017) 'Patients' hand washing and reducing hospital- acquired infection', Critical Care Nurse, 37(3), pp. e1-e8. doi: 10.4037/ccn2017694.

Jeong, S. Y. and Kim, K. M. (2016) 'Influencing Factors On Hand Hygiene Behavior Of Nursing Students Based On Theory Of Planned Behavior: A Descriptive Survey Study', Nurse Education Today, 36, pp. 159-164. doi: 10.1016/j.nedt.2015.09.014.

Kementerian Kesehatan Republik Indonesia (2009) 'Kebersihan Tangan Mempengaruhi Keselamatan Pasien'. Available at: https://www.kemkes.go.id/article/view/415/kebersihantangan-mempengaruhi-keselamatan-pasien.html (Accessed: 12 April 2021).

Kementerian Kesehatan Republik Indonesia (2017) 'Peraturan Menteri Kesehatan Republik Indonesia Nomor 27 Tahun 2017 Tentang Pedoman Pencegahan Dan Pengendalian Infeksi Di Fasilitas Pelayanan Kesehatan.'

Komala Dewi, R. R. (2017) 'Faktor Determinan Kepatuhan Perawat Dalam Melakukan Praktik Cuci Tangan Di Rsud Ade Muhammad Djoen Sintang.', Jurnal Kesmas (Kesehatan Masyarakat) Khatulistiwa, 4(3), p. 232. doi: 10.29406/jkmk.v4i3.865.

Mehta, Y. et al. (2014) 'Guidelines for prevention of hospital acquired infections', Indian Journal of Critical Care Medicine, 18(3), pp. 149-163. doi: 10.4103/0972-5229.128705.

Murni, I. K. et al. (2015) 'Reducing hospital-acquired infections and improving the rational use of antibiotics in a developing country: An effectiveness study', Archives of Disease in Childhood, 100(5), pp. 454-459. doi: 10.1136/archdischild-2014-307297.

Nurmala Sari, T. and Kurnia Widi Hastuti, S. (2019) 'Faktor-Faktor Yang Berhubungan Dengan Kepatuhan Perawat Dalam Pelaksanaan Hand Hygiene Di Ruang Rawat Inap RSU PKU Muhammadiyah Bantul'. http://eprints.uad.ac.id/14960/ (Accessed: 12 April 2021).

Perhimpunan Rumah Sakit Seluruh Indonesia (PERSI) (2020) Pelatihan Tingkat Dasar Pencegahan dan Pengendalian Infeksi di Rumah Sakit dan Pelayan Kesehatan LainnyaPERSI. Available at: https://persi.or.id/pelatihan-tingkat-dasar-pencegahan-danpengendalian-infeksi-di-rumah-sakit-dan-pelayan-kesehatan-lainnya/ (Accessed: 12 April 2021).

Purnawati, E., Junaiddin, J. and Mewanglo, M. (2018) 'Faktor yang Berhubungan dengan Kepatuhan Perawat dalam Melakukan Hand Hygiene Five Moment Di Ruang Rawat Inap RSUD Labuang Baji Makassar', Jurnal Ilmiah Kesehatan Diagnosis, 12(1), 14-. Available at: http://ejournal.stikesnh.ac.id/index.php/jikd/article/view/813 (Accessed: 12 April 2021).

Ratnawati, L. and Sianturi, S. R. (2018) 'Faktor-Faktor yang Berhubungan Dengan Kepatuhan 
Perawat dalam Menerapkan Hand Hygiene', Jurnal Ilmu Keperawatan dan Kebidanan, 9(2), p. 148. doi: 10.26751/jikk.v9i2.458.

Setiawan, Y. (2017) Faktor-Faktor Yang Berhubungan Dengan Kepatuhan Perawat Dalam Melakukan Cuci tangan Sebelum Dan Setelah Tindakan Keperawatan Diruang Punica Rumah Sakit Sentra Medika Cisalak Depok Tahun 2016, Jurnal Ilmiah Keperawatan. Available at: http://jurnal.imds.ac.id/imds/index.php/JIKep/article/view/56 (Accessed: 12 April 2021).

World Health Organization (WHO) (2017) 'WHO | The burden of health care-associated infection worldwide', WHO. Available at: http://www.who.int/infectionprevention/publications/burden_hcai/en/ (Accessed: 12 April 2021).

World Health Organization (WHO) (2018) WHO | Five moments for hand hygiene. Available at: https://www.who.int/gpsc/tools/Five_moments/en/.

Yoku, R. A. (2014) Faktor-Faktor yang Mempengaruhi Sikap Kebersihan Tangan pada Mahasiswa ETP 2012 Fakultas Keperawatan Universitas Pelita Harapan., Repository Universitas Pelita Harapan. Universitas Pelita Harapan. 